\title{
Strategi Pemasaran Produk Usaha Mikro di Kabupaten Probolinggo Pada Masa Pandemi Covid-19
}

\author{
Adil Abdillah \\ Universitas Mayjen Sungkono Mojokerto, Indonesia \\ email: ayah.adil1181@gmail.com
}

\begin{abstract}
This study aims to determine the constraints and problems in the marketing of micro business products in Probolinggo Regency so that it can be used in policy making by the local government for efforts to increase the marketing of the micro business. The object of this research is micro business actors in Probolinggo Regency. This research is a descriptive evaluative research using SWOT analysis technique, the data collection method is primary and secondary surveys. This research was conducted in July-August 2020. The analysis used was micro-enterprise data analysis, policy analysis, analysis of marketing potential and problems and analysis of micro-enterprise marketing strategy directions. Based on the analysis and identification of conditions in the field, the results of the micro business marketing strategy of Probolinggo Regency are located in quadrant I, meaning that in this quadrant it faces enormous market opportunities and internal strengths. The strategy set is Room A with Rapid Growth Strategy, which is a fast-flow growth strategy to show maximum development for certain targets and in a short time.
\end{abstract}

\section{Keywords: Strategy, Marketing, Micro Business Product}

\begin{abstract}
Abstrak: Penelitian ini bertujuan untuk mengetahui kendala dan pemasalahan dalam pemasaran produk usaha mikro di Kabupaten Probolinggo sehingga dapat digunakan dalam penyusunan kebijakan oleh pemerintah daerah untuk upaya peningkatan pemasaran usaha mikro. Dengan obyek penelitian adalah para pelaku usaha mikro di Kabupaten Probolinggo. Pada penelitian ini merupakan jenis penelitian deskriptif evaluatif dengan menggunakan teknik analisis SWOT, dengan metode pengumpulan datanya adalah survei primer dan sekunder. Penelitian ini dilaksanakan pada bulan Juli-Agustus 2020. Analisis yang digunakan adalah analisis data usaha mikro, analisis kebijakan, analisis potensi dan permasalahan pemasaran dan analisis arahan strategi pemasaran usaha mikro. Berdasarkan analisis dan identifikasi kondisi di lapangan dipeoleh hasil Strategi pemasaran usaha mikro Kabupaten Probolinggo terletak pada kuadran I, artinya dalam kuadran ini menghadapi peluang pasar dan kekuatan internal yang sangat besar. Adapun strategi yang ditetapkan adalah Ruang A dengan Rapid Growth Strategy, yaitu strategi pertumbuhan aliran cepat untuk diperlihatkan pengembangan secara maksimal untuk target tertentu dan dalam waktu singkat.
\end{abstract}

Kata Kunci: Strategi, Pemasaran, Produk Usaha Mikro

Copyright (c) 2021 The Authors. This is an open access article under the CC BY-SA 4.0 license (https://creativecommons.org/licenses/by-sa/4.0/)

\section{PENDAHULUAN}

Pelaku Usaha Mikro Kecil serta Menengah (UMKM) adalah roda penggerak perekonomian Indonesia. Ketika berdiskusi tentang bisnis serta ekonomi, terlebih tentang dunia usaha terkadang kita dihadapkan pada satu 
sebutan yang sangat berfungsi terhadap perekonomian adalah UMKM (Priharto, 2020). Dari namanya UMKM mempunyai kepanjangan Usaha Mikro, Kecil, serta Menengah (UMKM), tetapi jangan salah sang kecil ini mempunyai donasi yang sangat besar serta krusial untuk perekonomian Indonesia secara makro. Departemen Koperasi serta UKM RI memberikan data kalau secara jumlah unit, UMKM mempunyai pangsa berkisar 99, 99\% (62.9 juta unit) dari total totalitas pelaksana usaha di Indonesia (2017), sedangkan usaha besar cuma sebanyak 0,01\% ataupun kurang lebih 5400 unit. Usaha Mikro menyerap berkisar 107, 2 juta tenaga kerja (89, 2\%), Usaha Kecil 5,7 juta (4,74\%), serta Usaha Menengah 3, 73 juta ( 3, 11\%). Sedangkan Usaha Besar menyerap kurang lebih 3, 58 juta jiwa. Maksudnya secara keseluruhan UMKM menyerap kurang lebih 97\% tenaga kerja nasional, sedangkan Usaha Besar hanya mencapai 3\% dari total tenaga kerja nasional (Haryanti \& Hidayah, 2018).

Awal kontribusinya yang cukup baik terhadap perekonomian nasional ternyata Usaha mikro tergolong jenis usaha marjinal, karena masih terdapatnya permasalahan mendasar sehingga menghambat perkembangan usaha mikro tersebut, diantaranya adalah penggunaan teknologi yang relatif sederhana, tingkat modal yang rendah, akses terhadap kredit yang rendah, serta cenderung berorientasi pada pasar lokal (Kurniawan \& Fauziah, 2015)

Berdasarkan penelitian Adawiyah (2014) menerangkan jika hambatan dalam pengembangan UMKM di Kabupaten Banyumas dibagi jadi dua yaitu; aspek internal dan aspek internal. Aspek internal mencakup Terbatasnya modal, Terbatasnya kemahiran SDM, Lemahnya jaringan usaha serta akses pasar, Adapsi inovasi teknologi, Hambatan pembedahan (pemasaran serta pengendalian persediaan), Hambatan administratif (pembukuan serta manajemen secara universal). Sebaliknya buat aspek ekternal mencakup infra struktur/ fasilitas prasarana, hawa usaha, otonomi wilayah serta globalisasi. Berdasarkan pemahaman tersebut pastinya butuh terdapatnya kedudukan pemerintah daerah serta pihak pelaksana usaha mikro serta menengah untuk menanggulangi perihal tersebut, dengan mengelukan kebijkan wilayah sehingga bisa terpecahkannya permasalahan yang dialami oleh pelaksana usaha mikro. 
Pelaku Usaha Mikro Kecil serta Menengah (UMKM) saat ini, baik di bagian usaha jasa ataupun pembuatan hadapi bermacam- macam tantangan berat dalam keadaan pandemi Covid- 19 yang sudah berlangsung semenjak 3 bulan terakhir. Tantangan yang sangat banyak dialami oleh pelaku UMKM adalah terdapatnya penurunan omzet yang signifikan, sepinya pelanggan, kesusahan memperoleh bahan baku, serta hambatan pemasaran produk sebab terdapatnya Pembatasan Sosial Berskala Besar (PSBB) yang dilaksanakan di sebagian besar daerah Indonesia. Saat ini pelaku UMKM dihadapkan pada masa tatanan baru serta kenormalan baru ataupun lebih diketahui dengan istilah New Normal yang diisyarati dengan dibukanya kembali kegiatan keseharian warga dengan dengan tetap memepertahankan protokol kesehatan dari penyebaran pandemi Covid- 19 (Narto \& HM, 2020).

Jumlah usaha skala mikro di Kabupaten Probolinggo sangat tinggi, yakni sebesar 66.406 unit atau sebesar 87,11\% dari seluruh total usaha di Kabupaten Probolinggo(BPS Probolinggo, 2021). Sedangkan untuk usaha skala kecil terdapat sebanyak 8.987 unit atau sebanyak 11,79\%. Usaha skala besar menempati urutan jumlah terendah, yakni sebanyak 47 unit atau sebesar 0,06\% dari seluruh total usaha di Kabupaten Probolinggo. berdasarkan data Dinas Koperasi Dan Usaha Mikro Kabupaten Probolinggo terdapat 125 nama yang terdiri dari sektor industri, makanan dan minuman, jasa, batik, camilan dan handy craft (Dinas Koperasi Dan Usaha Mikro Kabupaten Probolinggo, 2020) .

Untuk lingkup Kabupaten/Kota yang memiliki kewenangan dalam pengembangan usaha mikro, memerlukan rumusan kebijakan yang lebih kondusif, koordinatif dan terintegrasi. Usaha mikro adalah badan usaha perorangan yang memiliki kriteria sesuai Undang-Undang (UU) Nomor 20 Tahun 2008 tentang Usaha Mikro, Kecil dan Menengah, yaitu memiliki aset atau kekayaan bersih hingga Rp 50 juta, tidak termasuk tanah atau bangunan tempat usaha dan omzet penjualan tahunan hingga Rp 300 juta. Sementara, berdasarkan perkembangannya, usaha mikro diklasifikan menjadi dua, yaitu : (1) Livelihood, yakni usaha mikro yang sifatnya untuk mencari nafkah semata. Jenis usaha mikro yang satu ini dikenal luas sebagai sektor informal. Contohnya, pedagang kaki lima dan (2) Mikro, yakni usaha mikro yang sudah cukup berkembang, namun memiliki sifat kewirausahaan 
dan belum bisa menerima perkerjaan sub kontraktor serta belum bisa melakukan kegiatan ekspor(Undang-Undang Republik Indonesia, 2008).

Berdasarkan latar berlakang tersebut penelitian ini bertujuan mengidentifikasi permasalahan produk usaha mikro yang ada di Kabupaten Probolinggo dan selanjutnya rumusan kebijakan alternatif yang dapat dilakukan pemerintah daerah sebagai rekomendasi dalam upaya meningkatkan pemasaran usaha mikro di Kabupaten Probolinggo. Dengan adanya kebijakan dari pemerintah daerah dapat mendoronng pertumbuhan ekonomi sektoral daerah melalui strategi pemasaran produk-produk usaha mikro yang banyak mengusung potensi dan produk unggulan daerah setempat dengan kekhasan dan keunikan tersendiri

\section{METODE}

Penelitian ini merupakan penelitian deskriftif evaluatif dengan menggunakan metode analisis SWOT dan EFAS IFAS. Penelitian dilaksanakan di seluruh wilayah kecamatan ayanga da di Kabupaten Probolinggo, dimana penelitian ini dilaksanakan pada bulan Juni sampai dengan Agustus tahun 2020.

Metode yang digunakan dalam penelitian ini adalah metode pendekan riset deskripstif. Riset deskriftif adalah sesuatu metode riset yang ditunjukkan untuk menggambarkan fenomena-fenomena yang terdapat, yang berlangsung pada disaat ini maupun dikala masa dulu sekali. Riset deskriftif sanggup mendeskripsikan kondisi saja, namun dapat pula mendeskripsikan tahapan-tahapan perkembangannya dan menggambarkan suatu keadaan sesuai dengan kenyataan yang ada (Saepul \& Baharuddin, 2014). Jenis Pendekatan yang digunakan dalam kegiatan ini adalah deskriptif evaluatif.

Penelitian ini menggunakan metode pengumpulan data dengan metode survey primer dan sekunder. Survey primer dengan wawancara, observasi dan kuisioner. Sedangkan survey sekunder dengan menggunakan studi literatur, dokumentasi dan data dari organisasi serta instansi terkait. Analisis yang digunakan dalam penelitian ini adalah analisis data usaha mikro, analisis kebijakan terkait, analisis potensi dan permsalahan pengembanagan permasalahan, dan analisis arahan strategi pemasaran usaha mikro.

\section{HASIL DAN PEMBAHASAN}




\section{1) Hasil Analisis Data usaha Mikro}

a) Karakteristik Jenis Usaha Mikro

Berdasarkan hasil survey diperoleh data bahwa karakteristik data usaha mikro di Kabupaten Probolinggo dibagi menjadi beberapa kelompok usaha, yakni aneka industri, bahan dasar sembako, kerajinan, makanan dan minuman, pertanian, dan tekstil.

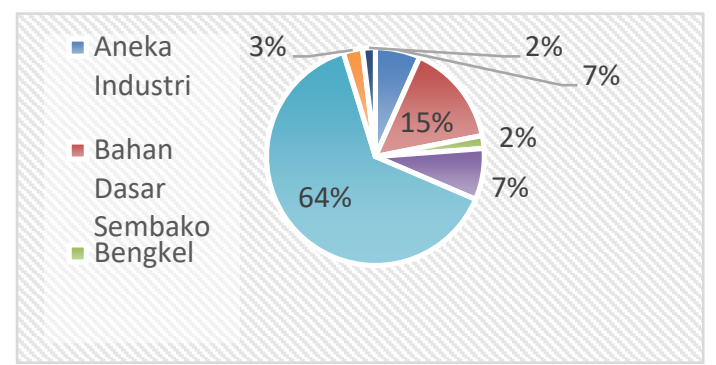

Gambar 1. Jenis Usaha Mikro di Kabupaten Probolinggo

Karakteristik jenis usaha mikro menentukan keberhasilan usaha tersebut dijalankan. Sesuai dengan penelitian yang dilakukan oleh (Safitri \& Khasan Setiaji, 2018) mengungkapkan bahwa karakteristik wirausaha mempengaruhi perkembangan usaha mikro, selain itu faktor modal juga menentukan perkembangan usaha mikro yang dijalankan.

b) Sumber produksi atau modal usaha mikro

Sumber produksi usaha mikro di Kabupaten Probolinggo memiliki jenis yang beragam, namun yang terbanyakadalah dana pribadi. Hal ini dikarenakan sebagian pelaku usaha merasa penggunaan bank terlalu rumit.

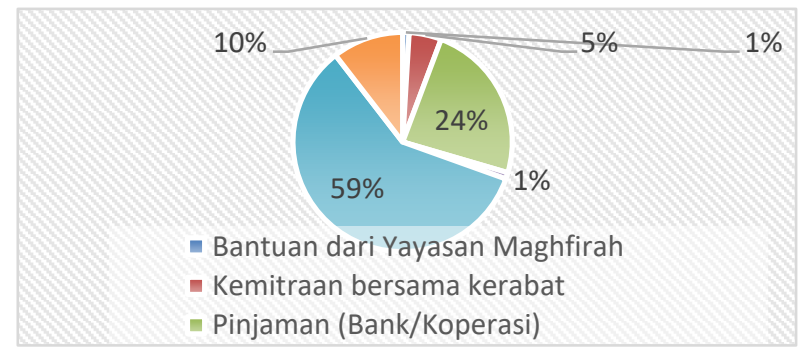

Gambar 2. Sumber Modal Usaha Mikro Kabupaten Probolinggo

Hasil survey dan analisis tersebut didukung oleh penelitian yang dilakukan oleh (Safanah, 2018) menyatakan bahwa sebagaian besar usaha mikro memiliki sumber modal berasal dari modal sendiri dan utang dari lembaga formal maupun non-formal. Tetapi permasalahannya adalah usaha UMKM dan usaha mikro ini memeiliki pencatatan keuangan yang belum 
terlalu baik dan rinci sehingga dapat mengancam usaha yang mareka jalankan.

c) Karaktertistik Sistem Pemasaran

Para pelaku usaha mikro dan UMKM memiliki tantangan besar dalam menjalankan usahanya yaitu adanya pemanfaatan IT, karena penggunaan IT dapat meningkatkan transformasi bisnis melalui kecepatan, ketepatan dan efisiensi pertukaran informasi dalam jumlah besar (Akhmad, 2015).

Namun di kabupaten Probolinggo sistem pemasaran usaha mikro mayoritas dilakukan secara manual sebanyak $73 \%$ dan hanya sebanyak $6,67 \%$ yang menggunakan media online. Hasil penjualan usaha mikro di Kabupaten Probolinggo dipasarkan mulai dari Kabupaten Probolinggo (72\%), Jawa Timur (17\%), dan Nasional (11\%). Tingkat kemitraan pada usaha mikro di Kabupaten Probolinggo dilakukan secara individu, yakni sebesar $78,10 \%$. Sedangkan untuk kemitraan, hanya 21,90\%. Kemitraan terbanyak terdapat pada jenis makanan dan minuman, yakni 12,38\%,

Berikut ini merupakan data pemasaran usaha mikro di Kabupaten Probolinggo, berdasarkan hasil survey dan beberapa data dari dinas terkait di Kabupaten Probolinggo;

Tabel 1.Persentase Pemasaran Usaha Mikro di Kabupaten Probolinggo

\begin{tabular}{lrcrc}
\hline & \multicolumn{4}{c}{ Jenis Pemasaran } \\
\cline { 2 - 5 } Jenis Usaha Mikro & Manual & $\begin{array}{c}\text { Manual } \\
\text { dan Online }\end{array}$ & $\begin{array}{c}\text { Manual } \\
\text { dan } \\
\text { Pameran }\end{array}$ & Online \\
\hline Aneka Industri & & & $0.00 \%$ & $1.90 \%$ \\
\hline Bahan Dasar Sembako & $12.38 \%$ & $0.95 \%$ & \\
\hline Bengkel & $1.90 \%$ & & $3.81 \%$ \\
\hline Kerajinan & $6.67 \%$ & $0.95 \%$ & \\
\hline Makanan dan & $46.67 \%$ & $10.48 \%$ & $2.86 \%$ & \\
Minuman & $0.95 \%$ & $1.90 \%$ & & \\
\hline Pertanian & & & & \\
\hline
\end{tabular}


227 | Jurnal Pendidikan dan Kewirausahaan Vol. 9 No. 12021

\begin{tabular}{|c|c|c|c|c|}
\hline Tekstil & $0.95 \%$ & & & $0.95 \%$ \\
\hline Total Kabupaten & $\mathbf{7 3 . 3 3 \%}$ & $17.14 \%$ & $2.86 \%$ & $6.67 \%$ \\
\hline
\end{tabular}

Sumber : Hasil Survey dan Analisis Tahun 2020

Sedangkan berikut merupakan tabel Data Tingkat Kemitraan Usaha Mikro di Kabupaten Probolinggo, berdasarkan atas hasil survey primer dan sekunder.

Tabel 2. Data Tingkat Kemitraan Usaha Mikro di Kabupaten Probolinggo

\begin{tabular}{lrr}
\hline \multirow{2}{*}{ Jenis Usaha Mikro } & \multicolumn{2}{c}{ Jenis Kemitraan } \\
\cline { 2 - 3 } & Bermitra & Individu \\
\hline Aneka Industri & $0.95 \%$ & $5.71 \%$ \\
\hline Bahan Dasar Sembako & $4.76 \%$ & $10.48 \%$ \\
\hline Bengkel & $3.81 \%$ & $1.90 \%$ \\
\hline Kerajinan & $12.38 \%$ & $51.43 \%$ \\
\hline Makanan dan Minuman & & $2.86 \%$ \\
\hline Pertanian & & $1.90 \%$ \\
\hline Tekstil & $\mathbf{2 1 . 9 0 \%}$ & $\mathbf{7 8 . 1 0 \%}$ \\
\hline \multicolumn{1}{c}{ Total Kabupaten }
\end{tabular}

Sumber : Hasil Survey dan Analisis Tahun 2020

Usaha mikro di Kabupaten Probolinggo mengalami gangguan akibat adanya wabah covid-19. Sebanyak $81 \%$ mengalami penurunan pendapatan dan omset, sedangkan yang lain mengalami gangguan bahan baku dan proses distribusi. Namun, terdapat 17\% masih dapat bertahan dengan penjualan yang stabil. Hal ini sejalan dengan penelitian (Amri, 2020) dimana dalam penelitian tersebut menyatakan bahwa terdapat penurunan omzet UMKM dan Koperasi di masa pandemi covid 19. Sektor yang paling terdampak adalah sektor industri wisata yang menyebabkan efek domino terhadap penurunan usaha lainnya yaitu usaha mikro makan dan minuman, usaha kerajinan, dan usaha mikro lainnya yang terakit pariwisata.

Tabel 3. Data PengaruhWabah Covid-19 Terhadap Usaha Mikro di Kabupaten Probolinggo 
228 | Jurnal Pendidikan dan Kewirausahaan Vol. 9 No. 12021

\begin{tabular}{|c|c|c|c|c|c|}
\hline \multirow{2}{*}{$\begin{array}{c}\text { Jenis Usaha } \\
\text { Mikro }\end{array}$} & \multicolumn{5}{|c|}{ Jenis Pengaruh Wabah Covid } \\
\hline & Menurun & Stabil & $\begin{array}{c}\text { Terganggu } \\
\text { bahan baku }\end{array}$ & $\begin{array}{c}\text { Terganggu } \\
\text { distribusi }\end{array}$ & Total \\
\hline Aneka Industri & $5.71 \%$ & $0.95 \%$ & & & $6.67 \%$ \\
\hline $\begin{array}{l}\text { Bahan Dasar } \\
\text { Sembako }\end{array}$ & $12.38 \%$ & $2.86 \%$ & & & $15.24 \%$ \\
\hline Bengkel & $0.95 \%$ & & $0.95 \%$ & & $1.90 \%$ \\
\hline Kerajinan & $5.71 \%$ & $1.90 \%$ & & & $7.62 \%$ \\
\hline $\begin{array}{l}\text { Makanan dan } \\
\text { Minuman }\end{array}$ & $54.29 \%$ & $9.52 \%$ & & & $63.81 \%$ \\
\hline Pertanian & $1.90 \%$ & & & $0.95 \%$ & $2.86 \%$ \\
\hline Tekstil & & $1.90 \%$ & & & $1.90 \%$ \\
\hline $\begin{array}{c}\text { Total } \\
\text { Kabupaten }\end{array}$ & $80.95 \%$ & $17.14 \%$ & $0.95 \%$ & $0.95 \%$ & $100.00 \%$ \\
\hline
\end{tabular}

Sumber : Hasil Survey dan Analisis Tahun 2020

Dari tabel tersebut dapat dilihat usaha mikro di kabupaten Probolinggo yang terdapak besar adalah usaha makanan dan minuman serta bahan dasar sembako. Dalam penelitian Kristian (2020) mengungkapkan bahwa salah satu cara bertahan bagu UMKM dan usaha mikro salah satunya dengan menggunakan strategi jangka pendek adalah bantuan pinjaman dan bantuan tunai baik dari pemerintah maupun swasta. Sedangkan untuk strategi jangka panjang adalah pemanfaatan teknologi ditigal.

d) Karakteristik terkait Kebijakan Pemerintah

Sebanyak $80 \%$ pelaku usaha mikro di Kabupaten Probolinggo tidak mengetahui kebijakan pemerintah terkait usaha mikro. Namun, terdapat $18,10 \%$ pelaku usaha yang mengetahui kebijakan tersebut. Hal ini dapat dikarenakan kurangnya sosialisasi pemerintah terkait sosialisasi pengetahuan kebijakan pemerintah dalam pengembangan usaha mikro. 


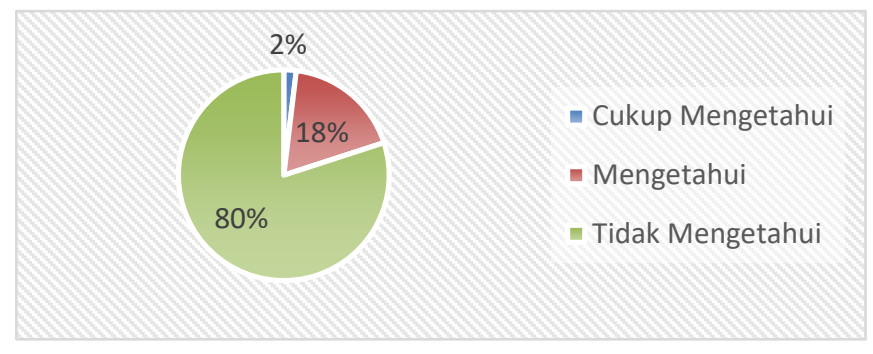

Gambar 3. Pengetahuan Usaha Mikro terhadap Kebijakan Pemerintah Kabupaten Probolinggo

Dari gambar tersebut terlihat masih cukup tinggi masyarakat pelaku usaha mikro di Kabupaten Probolinggo belum mengetahui kebijakan-kebijakan terkait usaha mikro yang berlaku di Kabupaten Probolinggo. untuk itu perlu peran aktif pemerintah dalam mensosialisasikan beberapa kebijakan yang terkait usaha mikro.

\section{2) Hasil Analisis Kebijakan Terkait}

Tujuan tahapan analisis ini untuk mendekonstruksi tulisan yang ada. Selain itu sebagai pengenalan pola untuk mengidentifikasi pola yang serupa dari informasi yang bersifat acak. Tujuannya mengklasifikasikan secara umum konsep yang ada dan kemudian melihat kemiripan pola secara lebih detail.

Tabel 4. Evaluasi Kebijakan dan Peraturan Terkait Usaha Mikro Kabupaten Probolinggo

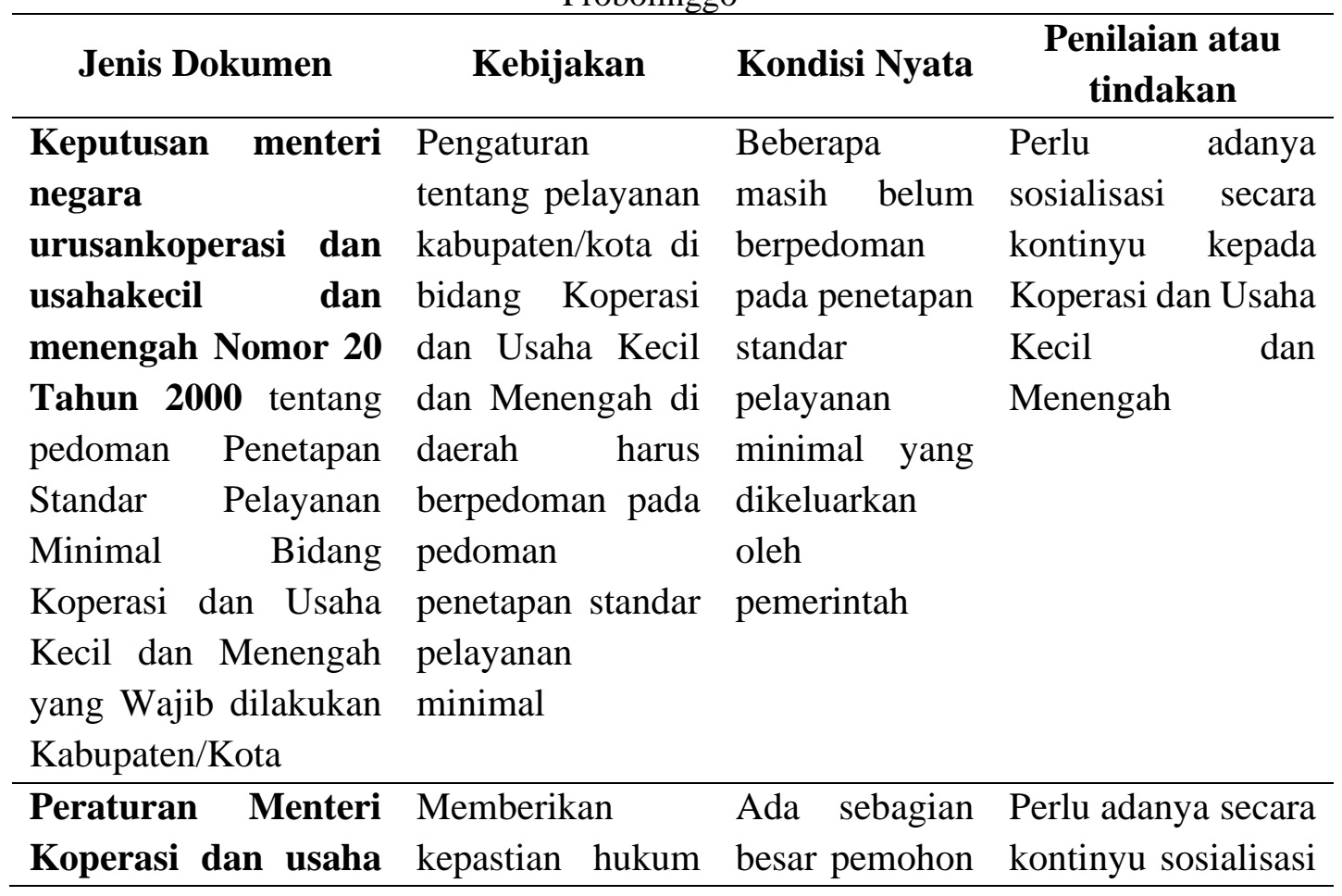




\begin{tabular}{|c|c|c|c|}
\hline Jenis Dokumen & Kebijakan & Kondisi Nyata & $\begin{array}{c}\text { Penilaian atau } \\
\text { tindakan }\end{array}$ \\
\hline $\begin{array}{l}\text { kecil dan Menengah } \\
\text { Nomor } 2 \text { tahun } 2019 \\
\text { tentang Perizinan } \\
\text { Berusaha Terintegrasi } \\
\text { secara Elektronik bagi } \\
\text { usaha Mikro dan Kecil } \\
\text { (Peraturan Mentri } \\
\text { Koperasi Dan Usaha } \\
\text { Kecil Dan Menengah, } \\
\text { 2019) }\end{array}$ & $\begin{array}{l}\text { dan sarana } \\
\text { pemberdayaan } \\
\text { bagi Pelaku Usaha } \\
\text { Mikro dan Usaha } \\
\text { Kecil } \\
\text { perseorangan } \\
\text { dalam } \\
\text { mengembangkan } \\
\text { usahanya. }\end{array}$ & $\begin{array}{l}\text { masih belum } \\
\text { paham alur dan } \\
\text { syarat- } \\
\text { syaratnya dari } \\
\text { perijinan usaha } \\
\text { dalam } \\
\text { mengembangk } \\
\text { an produknya, } \\
\text { meliputi tata } \\
\text { cara } \\
\text { permohonan } \\
\text { perijinan dan } \\
\text { masa berlaku }\end{array}$ & $\begin{array}{lr}\text { kepada } & \text { para } \\
\text { koperasi } & \text { dan usaha } \\
\text { kecil menengah } \\
\text { terkait } & \text { perizinan } \\
\text { yang } & \text { terintegrasi } \\
\text { secara } & \text { elektronik } \\
\text { oleh OPD terkait }\end{array}$ \\
\hline 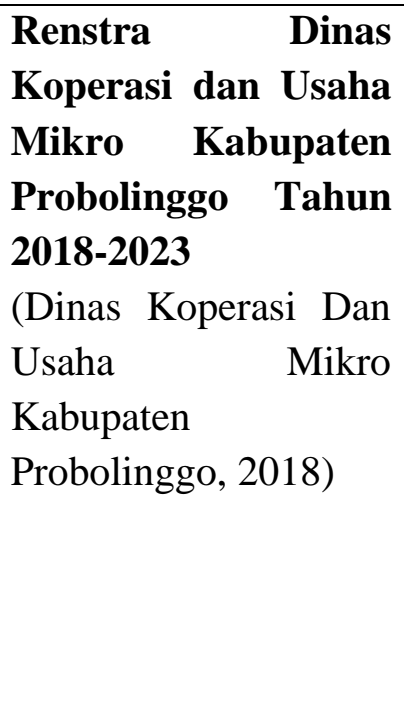 & $\begin{array}{l}\text { Meningkatkan } \\
\text { pemerataan } \\
\text { pendapatan } \\
\text { masyarakat } \\
\text { melalui Koperasi } \\
\text { dan Usaha Mikro } \\
\text { dan } \\
\text { Meningkatkan } \\
\text { Koperasi dan } \\
\text { Usaha Mikro yang } \\
\text { tangguh dan } \\
\text { mandiri }\end{array}$ & $\begin{array}{l}\text { Ada beberapa } \\
\text { program dan } \\
\text { Kegiatan yang } \\
\text { tertuangdalam } \\
\text { Renstra Dinas } \\
\text { Koperasi dan } \\
\text { Usaha Mikro } \\
\text { Kabupaten } \\
\text { Probolinggo } \\
\text { Tahun 2018- } \\
2023 \text { kurang } \\
\text { berjalan } \\
\text { maksimal }\end{array}$ & $\begin{array}{l}\text { Perlu melakukan } \\
\text { evaluasi berkala } \\
\text { terkait program dan } \\
\text { Kegiatan yang telah } \\
\text { dilaksankan dengan } \\
\text { tujuan hasil atau } \\
\text { outputnya sesuai } \\
\text { dengan renstra } \\
\text { dinas }\end{array}$ \\
\hline $\begin{array}{ll}\text { Peraturan } & \text { Bupati } \\
\text { Probolinggo } & \\
\text { Nomor : } 6 & \text { Tahun } \\
2020 & \\
\text { Tentang } & \\
\text { Dukungan } & \\
\text { Kelembagaan } & \text { Usaha } \\
\text { Mikro } & \end{array}$ & $\begin{array}{l}\text {-Menumbuhkan } \\
\text { dan } \\
\text { mengembangkan } \\
\text { kemampuan usaha } \\
\text { mikro yang } \\
\text { tangguh dan } \\
\text { mandiri } \\
\text {-Meningkatkan } \\
\text { peran serta usaha } \\
\text { mikro }\end{array}$ & $\begin{array}{l}\text { Adanya } \\
\text { Peraturan } \\
\text { Bupati } \\
\text { Probolinggo } \\
\text { Nomor: } 6 \\
\text { Tahun } 2020 \\
\text { Tentang } \\
\text { Dukungan } \\
\text { Kelembagaan } \\
\text { Usaha Mikro } \\
\text { diimbangi } \\
\text { dengan rencana }\end{array}$ & $\begin{array}{lr}\text { Dengan } & \text { adanya } \\
\text { Perbup } & \text { sebagai } \\
\text { cantolan } & \text { hokum } \\
\text { dalam rangka } & \text { memperkuat dan } \\
\text { pengembangan } \\
\text { kelembagaan usaha } \\
\text { mikro }\end{array}$ \\
\hline
\end{tabular}




\begin{tabular}{|c|c|c|c|}
\hline Jenis Dokumen & Kebijakan & Kondisi Nyata & $\begin{array}{c}\text { Penilaian atau } \\
\text { tindakan }\end{array}$ \\
\hline & & $\begin{array}{l}\text { aksi dan tindak } \\
\text { lanjut }\end{array}$ & \\
\hline
\end{tabular}

Sumber: Hasil Pemikiran, 2020

\section{3) Hasil Analisis Potensi dan Permasalahan}

Berdasarkan hasil survey yang dilakukan dilapangan didapatkan banyak usaha mikro yang potensial untuk dikembangkan. Berbagai bidang usaha mikro seperti perdagangan, pengrajin kayu, pembuat tahu tempe, batik sampai dengan usaha pengolahan makanan dan minuman. Tentunya dalam pengembangan produk usaha mikro perlu diimbangi dengan strategi pemasaran produk dan meminimalisir permasalahan-permasalahan yang muncul. Permsalahan dan kendala tersebut yaitu;

a) Sumber Daya Manusia/SDM

Salah satu permasalahan yang menjadi hambatan dalam mengembangkan usaha mikro Di Kabupaten Probolinggo adalah masih minimnya kualitas sumber daya manusia dan kurangnya SDM.

b) Modal Usaha

Berdasarkan hasil survey menggambarkan Sebagian besar mereka kekurangan modal usaha. Akibatya walaupun mempunyai rencana yang matang tetapi akses permodalan yang kurang maka pengembangan usaha menjadi terhambat

c) Bahan Baku Produksi

Keterbatasan bahan baku dan input-input lain juga sering menjadi salah satu masalah serius bagi pertumbuhan output atau kelangsungan produksi bagi produk usaha Mikro Di Kabupaten Probolinggo. Selain bahan baku produksi yang lokasi berjauhan dengan tempat produksi juga kendala lain seperti harga yang tidak stabil, bahan baku yang kadang sulit didapat dan kualitas yang kurang baik.

d) Pemasaran Hasil Usaha

Salah satu aspek yang terkait dengan masalah pemasaran yang umum dihadapi oleh usaha mikro adalah tekanan-tekanan persaingan, baik dipasar domestik dari produk-produk yang serupa buatan pengusaha-pengusaha besar dan impor. Selain itu kendala pada sistem pemasarannya yang sebagia besar 
usaha mikro di Kabupaten Probolinggo adalah masih menggunakan manual. Sedikit yang sudah menggunakan media online maupun keduanya.

e) Promosi Kegiatan

Berdasarkan survay yang dilakukan minimnya media promosi yang dilakukan secara online produk yang dihasilkan. Oleh karena itu perlu adanya peningkatan media promosi Kegiatan dari manual menuju online baik menggunakan sosial media atau yang lain

f) Pengetahuan Terkait Kebijakan/Perda Terkait Pengembangan Usaha Mikro

Hasil survay dilapangan menunjukan bahwa sebagian besar usaha mikro belum mengetahui kebijakan tersebut. Contohnya pada pengusaha pengolahan tempe Di Kecamatan Tiris dengan kelompok usaha bernama Jayananta. Sistem produksi usahanya adalah bahan yang diperoleh atau bahan mentah diolah menjadi bahan setengah jadi (tempe) dan kemudian dijual. Terkait dengan pengembangan dan kebijakan pengembangan usaha mikro mereka belum mengetahui.

g) Keterbatasan Teknologi

Keterbelakangan teknologi ini tidak hanya membuat rendahnya jumlah produksi dan efisiensi di dalam proses produksi, tetapi juga rendahnya kualitas produk yang dibuat serta kesanggupan bagi usaha mikro Di Kabupaten Probolinggo.

h) Keikutsertaan Pelatihan

Berdasarkan hasil survay yang dilakukan didapatkan bahwa masih banyak usaha mikro yang tidak mengikuti pelatihan yang diadakan dinas terkait atau instansi. Adapun faktor-faktor dari pengusaha mikro tidak mengikuti pelatihan dapat disebabkan oleh fakor ketidaktahuan terkait adanya pelaksanaan pelatihan dan Kurang kontinyu program dan pelatihan yang diberikan.

i) Sistem Perijinan

Hasil survay didapatkan secara umum para pengusaha mikro belum mengetahui tata cara dan sistem perijinan serta kendala pengajuan perijinan kegiatan usaha mikro.

Permasalahan tersebut juga didukung oleh penelitian Maryama (2018) yang menyatakan bahwa permasalahan utama yang dihadapi pada obyek 
penelitiannya yaitu usaha Pabrik Krupuk Manunggal Karsa antara lain adalah bahan baku, permodalan, kemitraaan dengan perbankan, SDM dan Pemasaran.

\section{4) Analisis Arahan Strategi Pemasaran Usaha Mikro}

$\rightarrow$ Analisis SWOT

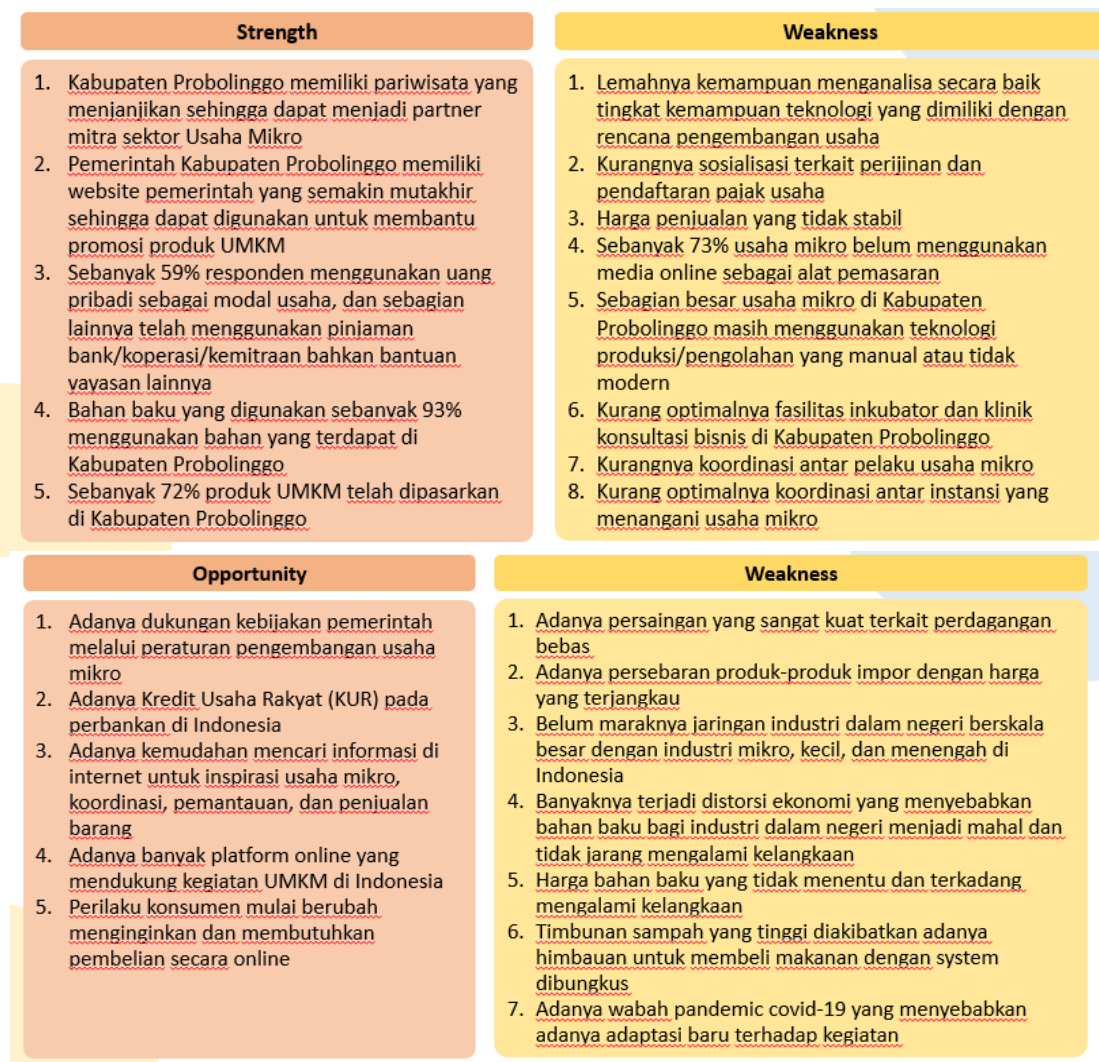

Gambar 3. Hasil Analisis SWOT

\section{$\rightarrow$ Analisis EFAS IFAS}

Analisis untuk mengetahui faktor-faktor yang menjadi kekuatan, kelemahan, peluang dan ancaman. Analisis ini merupakan lanjutan dari analisis SWOT.

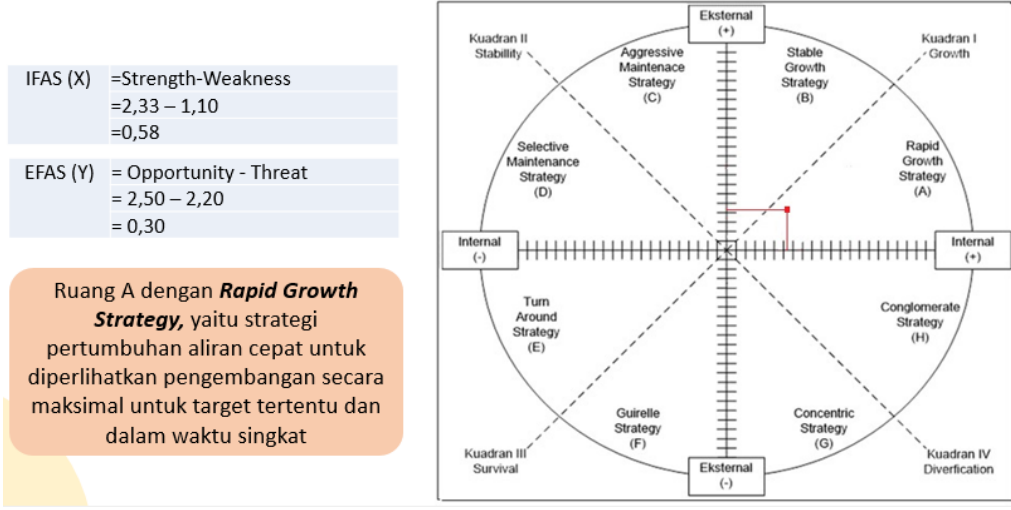

Gambar 4.Hasil Analisis EFAS IFAS 


\section{5) Rencana Pemasaran Produk Usaha Mikro Di Kabupaten Probolinggo}

Rencana pemasaran produk usaha mikro Kabupaten Probolinggo terbagi menjadi enam aspek sebagai berikut;

a) Aspek Sumber Daya Manusia

Aspek sumber daya manusia memiliki satu fokus, yakni peningkatan kualitas sumber daya manusia

Tabel 5. Rencana Strategis Aspek Sumber Daya Manusia

\begin{tabular}{|c|c|}
\hline Fokus & Rekomendasi Rencana Aksi \\
\hline \multirow{13}{*}{$\begin{array}{l}\text { Peningkatan } \\
\text { kualitas } \\
\text { Sumber Daya } \\
\text { Manusia }\end{array}$} & $\begin{array}{l}\text { Menyusun kelompok-kelompok usaha mikro untuk memudahkan } \\
\text { koordinasi dengan para stakeholder }\end{array}$ \\
\hline & $\begin{array}{l}\text { Mengadakan sosialisasi untuk mengoptimalkan bakat dan minat } \\
\text { penduduk sehingga dapat mengembangkan usaha mikro }\end{array}$ \\
\hline & Pengadaan sosialisasi penggunaan internet sebagai media bisnis \\
\hline & Pelatihan penyusunan business plan bagi pelaku usaha mikro \\
\hline & Pelatihan tata boga yang mudah, kekinian, dan menguntungkan \\
\hline & Pelatihan menjahit (fashion atau perabot rumah) \\
\hline & Pelatihan pembuatan asesoris sebagai oleh-oleh khas Probolinggo \\
\hline & $\begin{array}{l}\text { Memberikan sosialisasi penggunaan anggaran yang efektif dan } \\
\text { efisien }\end{array}$ \\
\hline & $\begin{array}{l}\text { Mengadakan sosialisasi terkait rumah kemasan (Krasnada) untuk } \\
\text { memperbaiki mutu packaging yang aman, nyaman, dan unik }\end{array}$ \\
\hline & $\begin{array}{l}\text { Melakukan pendampingan dan pengawasan terkait pelaksanaan } \\
\text { usaha mikro }\end{array}$ \\
\hline & $\begin{array}{l}\text { Memberikan sosialisasi terkait mengelola usaha dan menjadi } \\
\text { entreprenur yang sukses }\end{array}$ \\
\hline & $\begin{array}{l}\text { Memberikan sosialisasi terkait pengelolaan sampah dari kegiatan } \\
\text { usaha mikro }\end{array}$ \\
\hline & $\begin{array}{l}\text { Memberikan informasi link webinar gratis terkait pengembangan } \\
\text { usaha mikro melalui sosial media secara berkala }\end{array}$ \\
\hline
\end{tabular}

Sumber : Hasil Penyusunan Rencana, 2020

b) Aspek Modal

Aspek modal memiliki satu fokus dan tiga rekomendasi rencana aksi. Aspek modal menjelaskan terkait upaya untuk mengatasi modal, baik modal keuangan dan modal bahan baku yang digunakan untuk menjalankan kegiatan usaha mikro. 
Tabel 6. Rencana Strategis Aspek Modal

\begin{tabular}{ll}
\hline \multicolumn{1}{c}{ Fokus } & \multicolumn{1}{c}{ Rekomendasi Rencana Aksi } \\
\hline Pengadaan bantuan & Memberikan penyaluran modal dengan bunga lunak atau \\
modal untuk & bahkan tanpa bunga perlu diperjuangkan untuk disalurkan \\
pelaku usahamikro & kepada perempuan UMKM. \\
\cline { 2 - 2 } & $\begin{array}{l}\text { Memberikan bantuan bahan baku utama pelaku usaha mikro } \\
\text { yang kurang mampu namun berpotensi }\end{array}$ \\
\cline { 2 - 2 } & Memberikan bantuan tunai pada pelaku usaha mikro terpilih \\
\hline
\end{tabular}

Sumber : Hasil Penyusunan Rencana, 2020

c) Aspek Bahan

Rencana strategis aspek bahan memiliki satu fokus, yakni mengembangkan kemudahan untuk mendapatkan bahan. Kegiatan aspek ini terdiri dari tiga upaya.

Salah satunya berupa kemitraan bahan baku antar pelaku usaha mikro.

Tabel 7. Rencana Strategis Aspek Bahan

\begin{tabular}{|c|c|}
\hline Fokus & Rekomendasi Rencana Aksi \\
\hline \multirow{4}{*}{$\begin{array}{l}\text { Mengembangkan } \\
\text { kemudahan } \\
\text { mendapatkan bahan }\end{array}$} & Mengoptimalkan lembaga incubator \\
\hline & $\begin{array}{l}\text { meningkatkan kemitraan bahan baku antar pelaku usaha } \\
\text { mikro (misalnya pelaku makanan minuman dengan took } \\
\text { peracangan) }\end{array}$ \\
\hline & $\begin{array}{l}\text { Memberikan informasi kepada masyarakat untuk } \\
\text { mengamati promo tengah tahun, akhir tahun, hari besar, } \\
\text { dan lainnya sehingga dapat mendapatkan harga bahan } \\
\text { baku yang lebih terjangkau }\end{array}$ \\
\hline & $\begin{array}{l}\text { Meningkatkan peluang kemitraan dengan distributor di } \\
\text { daerah lain (melalui platform onlin eatau melalui } \\
\text { kerjasama antar pemerintah daerah) }\end{array}$ \\
\hline
\end{tabular}

Sumber : Hasil Penyusunan Rencana, 2020

d) Aspek Pasar

Rencana strategis aspek pasar dilakukan dengan dua fokus, yakni peningkatan penggunaan media online untuk pemasaran hasil usaha dan oleh oleh berbasis usaha mikro.

Tabel 8. Rencana Strategis Aspek Pasar

\begin{tabular}{|c|c|}
\hline Fokus & Rekomendasi Rencana Aksi \\
\hline Peningkatan & Mengadakan pelatihan analisis pasar bagi pelaku usaha mikro \\
\hline Penggunaan Media & di jaman millenial dan pandemi \\
\hline $\begin{array}{lr}\text { Online } & \text { untuk } \\
\text { pemasaran } & \text { hasil } \\
\text { usaha mikro } & \end{array}$ & $\begin{array}{l}\text { Mengadakan pelatihan pemanfaatan platform online shop } \\
\text { (shopee, tokopedia) dan media sosial(instagram, facebook, } \\
d s b \text { ) }\end{array}$ \\
\hline
\end{tabular}




\begin{tabular}{ll}
\hline \multicolumn{1}{c}{ Fokus } & \multicolumn{1}{c}{ Rekomendasi Rencana Aksi } \\
\hline & $\begin{array}{l}\text { Memberikan informasi tips and tricks memaksimalkan fiitur } \\
\text { iklan pada media online dan kemitraan berbayar (endorse) }\end{array}$ \\
\cline { 2 - 2 } & $\begin{array}{l}\text { Mengadakan pelatihan penggunaan e-money sehingga } \\
\text { pembayaran lebih mudah dan cepat }\end{array}$ \\
\cline { 2 - 2 } & Menghimbau gerakan Toko Peracangan/Warung online \\
\cline { 2 - 2 } Menyediakan oleh & $\begin{array}{l}\text { Meningkatkan kerjasama antar pelaku usaha mikro (baik di } \\
\text { dalam maupun di luar kabupaten) }\end{array}$ \\
\hline mikro & $\begin{array}{l}\text { Meningkatkan kerjasama dengan Dinas Pariwisata dan hotel } \\
\text { setempat untuk menggunakan jasa usaha mikro }\end{array}$ \\
\cline { 2 - 2 } & $\begin{array}{l}\text { Menyediakan stan oleh oleh khas Kabupaten Probolinggo } \\
\text { pada area strategis pariwisata }\end{array}$ \\
\cline { 2 - 2 } & $\begin{array}{l}\text { Mengoptimalkan kerjasama untuk memasarkan barang di } \\
\text { Toko Disperindag Kabupaten Probolinggo (terletak di } \\
\text { KecamatanTongas dan Kraksaan) }\end{array}$ \\
\hline
\end{tabular}

Sumber : Hasil Penyusunan Rencana, 2020

e) Aspek Metode

Aspek metode memiliki satu fokus, yakni meningkatkan kerjasama antar stake holder. Kerjasama ini dilakukan antara pemerintah, pelaku usaha mikro, akademisi, dan praktisi lembaga swasta atau perusahaan.

Tabel 9. Rencana Strategis Aspek Metode

\begin{tabular}{ll}
\hline \multicolumn{1}{c}{ Fokus } & \multicolumn{3}{c}{ Rekomendasi Rencana Aksi } \\
\hline Meningkatkan & Meningkatkan kerjasama dengan universitas untuk \\
kerjasam aantar stake & melakukan penelitian dan menghasilkan rekomendasi \\
holder & pengembangan usaha mikro \\
\cline { 2 - 3 } & $\begin{array}{l}\text { Meningkatkan kerjasama dengan universitas untuk } \\
\text { memberikan pelatihan }\end{array}$ \\
\cline { 2 - 2 } & $\begin{array}{l}\text { Meningkatkan kerjasama dengan lembaga swasta atau } \\
\text { perusahaan untuk memberikan pelatihan }\end{array}$ \\
\cline { 2 - 2 } & $\begin{array}{l}\text { Meningkatkan kerjasama dengan lembaga swasta atau } \\
\text { perusahaan sebagai mitra pengembangan usaha mikro }\end{array}$ \\
& Meningkatkan kerjasama antar OPD terkait dengan \\
perijinan usaha mikro supaya tidak terjadi tumpang tindih
\end{tabular}

Sumber : Hasil Penyusunan Rencana, 2020

f) Aspek Alat

Rencana pemasaran aspek alat memiliki tiga fokus yang bertujuan untuk meningkatkan fungsi sarana prasarana yang aplikatif dan memudahkan pelaksanaan 
usaha, memberikan apresiasi ataupun sanksi terhadap pelaku usaha mikro sesuai dengan kegiatannya, dan mengoptimalkan legalitas hukum untuk menjamin keberlangsungan usaha mikro di Kabupaten Probolinggo.

Tabel 10. Rencana Strategis Aspek Alat

\begin{tabular}{|c|c|}
\hline Fokus & Rekomendasi Rencana Aksi \\
\hline \multirow{7}{*}{$\begin{array}{l}\text { Meningkatkan } \\
\text { fungsi sa } \\
\text { prasarana } \\
\text { mudah } \\
\text { diaplikasikan }\end{array}$} & $\begin{array}{l}\text { Menyusun Standart Operation Procedure (SOP) terkait } \\
\text { perijinan pembangunan usaha mikro di Kabupaten } \\
\text { Probolinggo }\end{array}$ \\
\hline & $\begin{array}{l}\text { Menyusun Standart Operation Procedure (SOP) terkait } \\
\text { quality control barang sebelum dipasarkan }\end{array}$ \\
\hline & $\begin{array}{l}\text { Memberikan bantuan koneksi internet atau ruang baca } \\
\text { sehingga dapat meningkatkan inspirasi pengembangan } \\
\text { produk }\end{array}$ \\
\hline & $\begin{array}{l}\text { Mengoptimalkan sosial media pemerintah/kepala daerah } \\
\text { untuk membagikan informasi terkait usaha, webinar, dan lain } \\
\text { lain }\end{array}$ \\
\hline & $\begin{array}{l}\text { Membangun aplikasi sebagai call center untuk terhubung } \\
\text { dengan para pelaku usaha mikro (menerima aspirasi dan } \\
\text { memantau perkembangan) }\end{array}$ \\
\hline & $\begin{array}{l}\text { Membangun database berbasis } G I S \text { untuk meningkatkan data } \\
\text { usaha mikro yang valid dan tersinergi (dapat digunakan untuk } \\
\text { pajak, kesesuaian tata ruang, dan lain lain) }\end{array}$ \\
\hline & Updating data pelaku usaha mikro \\
\hline \multirow{5}{*}{$\begin{array}{l}\text { Memberikan } \\
\text { insentif dan } \\
\text { disinsentif bagi } \\
\text { pelaku usaha mikro }\end{array}$} & $\begin{array}{l}\text { Memberikan apresiasi alat modern untuk usaha mikro } \\
\text { unggulan }\end{array}$ \\
\hline & $\begin{array}{l}\text { Memberikan bantuan akomodasi bagi usaha mikro yang } \\
\text { berhasil mengikuti pameran di luar negeri }\end{array}$ \\
\hline & $\begin{array}{l}\text { Memberikan keringanan pajak bagi usaha mikro yang ramah } \\
\text { lingkungan }\end{array}$ \\
\hline & $\begin{array}{l}\text { Memberikan sanksi/mencabut ijin pelaku usaha mikro yang } \\
\text { menggunakan bahan bahan tidak sehat pada makanan }\end{array}$ \\
\hline & $\begin{array}{l}\text { Membatasi atau mencabut kegiatan usaha mikro yang } \\
\text { mencemari lingkungan }\end{array}$ \\
\hline \multirow{4}{*}{$\begin{array}{l}\text { Mengoptimalkan } \\
\text { legalitas hukum } \\
\text { kebijakan } \\
\text { pemerintah terkait } \\
\text { usaha mikro }\end{array}$} & dakan sosialisasi terkait perijinan usaha mikro \\
\hline & $\begin{array}{l}\text { Meningkatkan kemitraan melalui lembaga layanan } \\
\text { pengembangan usaha dan inkubator }\end{array}$ \\
\hline & $\begin{array}{l}\text { Memberikan izin usaha yang cepat, transparan, murah, dan } \\
\text { pasti merupakan aspek kunci yang harus ada dalam setiap } \\
\text { usaha pengembangan UMKM }\end{array}$ \\
\hline & Mengajukan stimulus daya beli produk UMKM dan koperasi \\
\hline
\end{tabular}




\begin{tabular}{ll}
\hline Fokus & \multicolumn{1}{c}{ Rekomendasi Rencana Aksi } \\
\hline & $\begin{array}{l}\text { Bantuan pengembangan UMKM dalam bentuk pelayanan di } \\
\text { bidang hukum, misalnya atas kepemilikan asset produktif. }\end{array}$ \\
\cline { 2 - 2 } & Menghimbau kepada pusat perbelanjaan untuk \\
& memprioritaskan penjualan barang local atau hasil produk \\
& usaha mikro yang terdapat di Kabupaten Probolinggo \\
\cline { 2 - 2 } & Pemerintah meningkatkan pemantauan pelaku usaha mikro \\
& sehingga mampu bersaing sehat dengan industri besar serta \\
& perdagangan bebas \\
\hline
\end{tabular}

Sumber : Hasil Penyusunan Rencana, 2020

\section{SIMPULAN}

Berdasarkan hasil analisis dan pembahasan, diketahui bahwa beberapa karakteristik jenis usaha mikro sebagai berikut;

1. Jenis usaha mikro

Karakteristik jenis usaha mikro di Kabupaten Probolinggo sangat beragam, yakni Aneka Industri, Bahan Dasar Sembako, Bengkel, Kerajinan, Makanan dan Minuman, Pertanian, dan Tekstil.

2. Sumber Produksi Usaha Mikro

Sumber produksi usaha mikro di Kabupaten Probolinggo memiliki jenis yang beragam, namun yang terbanyak adalah dana pribadi. Hal ini dikarenakan sebagian pelaku usaha merasa penggunaan bank terlalu rumit.

3. Karakteristik Sistem Pemasaran

Sistem pemasaran usaha mikro mayoritas dilakukan secara manual sebanyak $73 \%$ dan hanya sebanyak $6,67 \%$ yang menggunakan media online. Hasil pemasarannya terbesar masih menjangkau pasar lokal sebanyak $72 \%$.

4. Karakteristik terkait kebijakan pemerintah

Sebanyak $80 \%$ pelaku usaha mikro di Kabupaten Probolinggo tidak mengetahui kebijakan pemerintah terkait usaha mikro. Namun, terdapat $18,10 \%$ pelaku usaha yang mengetahui kebijakan tersebut. Hal ini dapat dikarena kankurangnya pengetahuan pelaku usaha mikro terkait kebijakan pemerintah dalam pengembangan usaha mikro. Sehingga berpengaruh terhadap keikutsertaan pelatihan usaha mikro yang rendah. Sedangkan untuk pengetahuan terkait pengurusan perijinan juga masih rendah, sehingga hal ini 
berpengaruh terhadap status pajak usaha mikro yang belum terdaftar masih cukup tinggi.

Beberapa Permasalahan terkait dengan Penyusunan Strategi Pemasaran Produk Usaha Mikro Kabupaten Probolinggo adalah minimnya SDM, Kurangnya modal, keterbatasan bahan baku produksi, minimnya jaringan pemasaran dan kurangnya promosi.

Strategi pemasaran usaha mikro Kabupaten Probolinggo terletak pada kuadran I, artinya dalam kuadran ini menghadapi peluang pasar dan kekuatan internal yang sangat besar. Adapun strategi yang ditetapkan adalah Ruang A dengan Rapid Growth Strategy, yaitu strategi pertumbuh analiran cepat untuk diperlihatkan pengembangan secara maksimal untuk target tertentu dan dalam waktu singkat.

\section{DAFTAR RUJUKAN}

Adawiyah, W. R. (2014). Faktor Penghambat Pertumbuhan Usaha Mikro Kecil Menengah (UMKM): Studi di Kabupaten Banyumas. JKMP (Jurnal Kebijakan Dan Manajemen Publik), 2(2), 165.

Akhmad, K. A. (2015). Pemanfaatan Media Sosial bagi Pengembangan Pemasaran UMKM (Studi Deskriptif Kualitatif pada Distro di Kota Surakarta). DutaCom Journal, $9(1), \quad$ 43-54. http://journal.stmikdb.ac.id/index.php/dutacom/article/view/17

Amri, A. (2020). Dampak Covid-19 Terhadap UMKM di Indonesia. Jurnal Brand, 2(1), 123-130. https://www.academia.edu/42672824/Dampak_Covid19_Terhadap_UMKM_di_Indonesia

BPS Probolinggo, K. (2021). Kabupaten Probolinggo Dalam Angka 2021. CV. Azka Putra Pratama.

Dinas Koperasi Dan Usaha Mikro Kabupaten Probolinggo. (2018). Rencana Strategis (RENSTRA) Tahun 2018-2023.

Dinas Koperasi Dan Usaha Mikro Kabupaten Probolinggo. (2020). Data UKM Binaan Dinas Koperasi dan Usaha Mikro Kabupaten Probolinggo.

Haryanti, D. M., \& Hidayah, I. (2018). Potret UMKM Indonesia: Si Kecil yang Berperan Besar | UKM Indonesia. UKM Indonesia. https://www.ukmindonesia.id/baca-artikel/62 
240 | Jurnal Pendidikan dan Kewirausahaan Vol. 9 No. 12021

Kristian, A. (2020). Covid-19 Dan Implikasi Bagi Usaha Mikro, Kecil, Dan Menengah. Jurnal Ilmiah Hubungan Internasional, O(0), 59-64. https://doi.org/10.26593/jihi.v0i0.3870.59-64

Kurniawan, F. D., \& Fauziah, L. (2015). Pemberdayaan Usaha Mikro Kecil Dan Menengah (UMKM) Dalam Penanggulangan Kemiskinan. JKMP (Jurnal Kebijakan Dan Manajemen Publik), 53(9), 1689-1699.

Maryama, S. (2018). Permasalahan Manajemen Usaha Mikro Studi Kasus Pada Pabrik Kerupuk UD. Manunggal Karsa Di Kel. Lebak Bulus Kec. Cilandak Kodya Jakarta Selatan. Liquidity, 1(1), 81-90. https://doi.org/10.32546/lq.v1i1.159

Narto, N., \& HM, G. B. (2020). Penguatan Strategi Pemasaran Pudak di Tengah Pandemi Covid-19 untuk Meningkatkan Keunggulan Bersaing Usaha Mikro Kecil Menengah Kota Gresik. Jurnal INTECH Teknik Industri Universitas Serang Raya, 6(1), 48-54. https://doi.org/10.30656/intech.v6i1.2195

Peraturan Mentri Koperasi Dan Usaha Kecil Dan Menengah. (2019). Peraturan Menteri Koperasi Dan Usaha Kecil Dan Menengah Republik Indonesia Nomor 02 Tahun 2019 Tentang Perizinan Berusaha Terintegrasi Secara Elektronik Bagi Usaha Mikro Dan Kecil. Jakarta, 8(5), 55.

Permatasari, I. A. (2020). Kebijakan Publik (Teori, Analisis, Implementasi Dan Evaluasi Kebijakan). TheJournalish: Social and Government, 1, 34-38. http://thejournalish.com/ojs/index.php/thejournalish/article/view/7

Priharto, S. (2020). Pengertian, Kriteria, Contoh, Cara Ekspansi dan Regulasi yang Menaunginya. Accurate. https://accurate.id/bisnis-ukm/umkmadalah/\#1_Usaha_Mikro

Saepul, H., \& Baharuddin, E. (2014). Metode Penelitian Kuantitatif Aplikasi Dalam Pendidikan (A. Anas (ed.); 1st ed.). Deepublish.

Safanah, E. (2018). Sumber Modal Pada Usaha Kecil Makanan Ringan Desa Kelangonan Gresik. Jurnal Riset Entrepreneurship, 1(2), 64. https://doi.org/10.30587/jre.v1i2.417

Safitri, H., \& Khasan Setiaji. (2018). Pengaruh Modal Usaha dan Karakteristik Wirausaha Terhadap Perkembangan Usaha Mikro dan Kecil di Desa Kedungleper Kecamatan Bangsri Kabupaten Jepara. Economics Education 
241 | Jurnal Pendidikan dan Kewirausahaan Vol. 9 No. 12021

Analysis Journal, 7(2), 792-800.

Undang-Undang Republik Indonesia. (2008). Undang-Undang No. 20 Tahun 2008 tentang Usaha Mikro, Kecil, dan Menengah. Jakarta. https://peraturan.bpk.go.id/Home/Details/39653/uu-no-20-tahun-2008 